\title{
Remediation and rehabilitation
} programmes for health professionals: challenges for the future

\author{
François Goulet, Johanne Thiffault, Roger Ladouceur
}

Practice Enhancement Division, Collège des médecins du Québec, Montréal, Québec, Canada

\section{Correspondence to} Dr François Goulet, Practice Enhancement Division, Collège des médecins du Québec, 1250 Boulevard René-Lévesque 0 , Montréal, QC H3B 0G2, Canada; fgoulet@cmq.org

Accepted 4 September 2017 Published Online First

25 September 2017

\section{GLinked}

- http://dx.doi.org/10.1136/ bmjqs-2017-006710

CrossMark

To cite: Goulet F, Thiffault J, Ladouceur R. BMJ Qual Saf 2017;26:941-943.
'To improve is to change; to be perfect is to change often.'

$$
\text { —Winston Churchill }
$$

Health professions regulatory authorities are responsible for assessing the clinical performance of healthcare professionals. ${ }^{12}$ Some of them also have the responsibility for programming remediation interventions for health professionals with deficits in clinical performance. ${ }^{2} 3$ Available data on medical errors, malpractice claims, disciplinary actions and various other sources suggest that between $6 \%$ and $12 \%$ of physicians meet criteria for 'dyscompetence' in the USA. ${ }^{5}$ Elsewhere, the percentage varies according to the data sources. ${ }^{6}$ In Ontario, for instance, where the data come from randomly selected physicians, it is estimated that approximately $15 \%$ of family physicians and 3\% of specialists have considerable deficiencies. ${ }^{48}$ Performance problems can have an impact on quality of care and patient safety. ${ }^{5}$ Consequently, the problems must be addressed promptly and effectively.

The present article by Weenink et al provides a systematic review of the outcomes of rehabilitation and remediation programmes for healthcare professionals. $^{6}$ The authors' systematic review revealed that the literature comes primarily from North America and that many papers reported very positive outcomes for substance abuse programmes. As for competency remediation programmes, the number of papers published is smaller and the outcomes are more variable. This review provides an essential summary of the state of the literature regarding the support and development of rehabilitation and competency remediation programmes. It has important implications for the future of physician health programmes. The authors strongly encourage all health professions authorities in North America, Europe and elsewhere, to publish the long-term follow-up results of their rehabilitation and remediation programmes.

Healthcare professionals enrolled in physician health or remediation programmes often struggle with one or many of the following issues: knowledge deficits, clinical reasoning problems, communication problems, behavioural or technical skills difficulties, physical health issues, cognitive illnesses or substance abuse. Some of them have poor insight or no motivation to change their behaviour, which tends to increase the educational challenges faced by regulatory authorities in the development of efficient rehabilitation and remedial programmes. Deficits in health professional performance can be related to individual characteristics (age, health, financial situation), and also to the clinical context in which they practice (isolation, heavy workload, lack of resources). ${ }^{5-12}$ For these reasons, the drawing up of a rehabilitation or remedial programme must be based on an individualised approach tailored to the specific needs and limitations of each healthcare professional. ${ }^{13-15}$

It is well recognised that healthcare professionals constitute a high-risk group for substance abuse problems (because of the easier access to drugs) and for mental health problems (because of their high level of stress at work). ${ }^{11}$ The most successful rehabilitation programmes for monitoring and treating healthcare professionals are those that are based on a confidential and non-disciplinary approach. ${ }^{16}$ Weenink and colleagues ${ }^{6}$ point out that most programmes 
reported on in the literature focus on outcomes for physicians. The authors encourage programmes for other healthcare professionals, such as dentists, pharmacists, nurses and psychologists, to report on their outcomes. They also draw attention to the fact that most of the programmes for which the outcomes are documented operate in North America. This finding raises a number of questions. Why have other countries (eg, in Europe or Asia) not produced any studies of the prevalence of substance abuse disorders among health professionals? How are other countries dealing with physicians experiencing disorders or illnesses affecting their competence? Health professions regulatory authorities must develop programmes to screen, diagnose and treat health professionals affected by these disorders, but most importantly, they should publish the results of these programmes so that others may learn from them.

Whereas numerous studies focus on remediation, residency retraining and health programmes for undergraduate and postgraduate medical students, only a few studies address the effectiveness of remedial programmes for practising health professionals and include systematic follow-up over time. ${ }^{2}$ Some authors have reported the short-term results of their remedial educational programmes, showing a success rate of $70 \%-85 \%$, but long-term follow-up data remain generally not available. ${ }^{13}{ }^{14}$ Some individual factors have been recognised as exerting a negative impact on the outcomes of remediation, such as age (older than 60), mild cognitive impairment (eg, from early dementia or comorbid medical conditions) or mental illness (mood disorders) and substance abuse..$^{513}$

Many countries are now facing a critical shortage of healthcare professionals, with population growth and ageing being the most important drivers of the shortage. ${ }^{17} 18$ In the USA, it was recently estimated that 52000 additional primary care physicians will be required by the year $2025 .{ }^{19}$ Although medical schools are trying to keep up with the increasing needs for healthcare resources, clearly part of the solution lies in a better use of competent existing resources. The cost of rehabilitation or remediation programmes for healthcare professionals facing clinical performance problems is significantly lower than the cost of educating and training new ones. Early detection of dyscompetent health professionals may be the best way to ensure public safety. ${ }^{20-22}$ When screened at earlier stages of their health issues or competency problems, health professionals can be helped through rehabilitation or remedial programmes. In this manner, they will continue to offer high-quality healthcare. In conclusion, rehabilitation and remediation programmes for healthcare professionals are and will remain very important in the future, and more studies are needed to evaluate and compare the different programmes developed by regulatory authorities to help healthcare professionals overcome their performance problems.

Competing interests None declared.

Provenance and peer review Commissioned; internally peer reviewed.

(C) Article author(s) (or their employer(s) unless otherwise stated in the text of the article) 2017. All rights reserved. No commercial use is permitted unless otherwise expressly granted.

\section{REFERENCES}

1 Finucane PM, Bourgeois-Law GA, Ineson SL, et al. A comparison of performance assessment programs for medical practitioners in Canada, Australia, New Zealand, and the United kingdom. Acad Med 2003;78:837-43.

2 Humphrey C. Assessment and remediation for physicians with suspected performance problems: an international survey. J Contin Educ Health Prof 2010;30:26-36.

3 Hanna E, Premi J, Turnbull J. Results of remedial continuing medical education in dyscompetent physicians. Acad Med 2000;75:174-6.

4 Grace ES, Wenghofer EF, Korinek EJ. Predictors of physician performance on competence assessment: Findings from CPEP, the Center for Personalized Education for Physicians. Acad Med 2014;89:912-9.

5 Williams BW. The prevalence and special educational requirements of dyscompetent physicians. J Contin Educ Health Prof 2006;26:173-91.

6 Weenink JW, Kool RB, Bartels RH, et al. Getting back on track: a systematic review of the outcomes of remediation and rehabilitation programmes for healthcare professionals with performance concerns. BMJ Qual Saf 2017;26:944-6.

7 McAuley RG, Paul WM, Morrison GH, et al. Five-year results of the peer assessment program of the College of Physicians and Surgeons of Ontario. CMAJ 1990;143:1193-9.

8 Wenghofer EF, Williams AP, Klass DJ. Factors affecting physician performance: implications for performance improvement and governance. Healthc Policy 2009;5:e141-e160.

9 Hays RB, Jolly BC, Caldon LJ, et al. Is insight important? Measuring capacity to change performance. Med Educ 2002;36:965-71.

10 Leape LL, Fromson JA. Problem doctors: is there a systemlevel solution? Ann Intern Med 2006;144:107-15.

11 McLellan AT, Skipper GS, Campbell M, et al. Five year outcomes in a cohort study of physicians treated for substance use disorders in the United States. BMJ 2008;337:a2038.

12 van den Goor MM, Wagner CC, Lombarts KM. Poor physician performance in the Netherlands: characteristics, causes, and prevalence. J Patient Saf 2015.

13 Goulet F, Gagnon R, Gingras ME. Influence of remedial professional development programs for poorly performing physicians. J Contin Educ Health Prof 2007;27:42-8.

14 Goulet F, Jacques A, Gagnon R. An innovative approach to remedial continuing medical education, 1992-2002. Acad Med 2005;80:533-40.

15 Lillis S, Takai N, Francis S. Long-term outcomes of a remedial education program for doctors with clinical performance deficits. J Contin Educ Health Prof 2014;34:96-101. 
16 Tyssen R. Health problems and the use of health services among physicians: a review article with particular emphasis on Norwegian studies. Ind Health 2007;45:599-610.

17 Smith SD. The global workforce shortages and the migration of medical professions: the Australian policy response. Aust New Zealand Health Policy 2008;5:7.

18 Guilbert JJ. The World Health Report 2006: working together for health. Educ Health 2006;19:385-7.

19 Petterson SM, Liaw WR, Phillips RL, et al. Projecting US primary care physician workforce needs: 2010-2025. Ann Fam Med 2012;10:503-9.
20 Bismark MM, Spittal MJ, Gurrin LC, et al. Identification of doctors at risk of recurrent complaints: a national study of healthcare complaints in Australia. BMJ Qual Saf 2013;22:532-40.

21 Elkin K, Spittal MJ, Elkin D, et al. Removal of doctors from practice for professional misconduct in Australia and New Zealand. BMJ Qual Saf 2012;21:1027-33.

22 Shojania KG, Dixon-Woods M. 'Bad apples': time to redefine as a type of systems problem? BMJ Qual Saf 2013;22:528-31. 